\title{
Ortaöğretim Okulu Öğretmenlerinin Öğretmen Liderliğine İlişkin Algı ve Beklentileri
}

\author{
Yrd. Doç. Dr. Ali Çağatay KILINÇ \\ Karabük Üniversitesi, Edebiyat Fakültesi, Karabük / Türkiye \\ Yrd. Doç. Dr. Ergün RECEPOĞLU* \\ Kastamonu Üniversitesi, Eğitim Fakültesi, Kastamonu / Türkiye
}

\section{Özet}

$\mathrm{Bu}$ araştırmanın amacı ortaöğretim okulu öğretmenlerinin öğretmen liderliğine ilişkin algı ve beklentilerinin incelenmesidir. Araştırmaya Kastamonu il sınırları içinde bulunan ortaöğretim okullarında görev yapan toplam 291 öğretmen katılmıştır. Araştırma verileri, Beycioğlu ve Aslan (2010) tarafından geliştirilen "Öğretmen Liderliği Ölçeği" ile toplanmıştır. Araştırma verilerinin analizinde aritmetik ortalama, standart sapma, t-testi, ANOVA ve Pearson Momentler Çarpım Korelasyon Katsayısı kullanılmıştır. Araştırma sonuçları ortaöğretim okulu öğretmenlerinin öğretmen liderliğine ilişkin beklenti düzeylerinin algı düzeylerinden daha yüksek olduğunu göstermektedir. Araştırma sonucunda, öğretmenlerin liderlik rollerine ilişkin beklentilerinin cinsiyet değişkenine göre öğretmen liderliğinin kurumsal gelişme ve meslekî gelişim boyutlarında; algılarının ise yaş değişkenine göre kurumsal gelişme boyu- 
tunda ve meslekî kıdem değişkenine göre kurumsal gelişme ve meslektaşlarla iş birliği boyutlarında anlamlı farklılık gösterdiği belirlenmiştir. Son olarak araştırma sonuçları, öğretmenlerin liderlik rollerine ilişkin algı ve beklentileri arasında pozitif yönde anlamlı ilişkilerin olduğunu göstermektedir. Araştırmanın sonunda elde edilen sonuçlar ışı̆̆ında birtakım öneriler sunulmuştur.

Anahtar Kelimeler: Öğretmen liderliği; Öğretmen liderlik rolleri; Ortaöğretim; Öğretmenlerin algıları; Öğretmenlerin beklentileri.

\title{
High School Teachers' Perceptions on and Expectations from Teacher Leadership
}

\begin{abstract}
The purpose of this study was to determine high school teachers' perceptions on and expectations from teacher leadership roles. A total of 291 teachers employed in high schools in Kastamonu participated in this study. Research data was gathered via "Teacher Leadership Scale" developed by Beycioğlu and Aslan (2010). Arithmetic mean, standard deviation, t-test, ANOVA, and Pearson Product-Moment Correlation Coefficients were conducted to analyze the data. Results revealed that high school teachers' expectation level was higher than their perception level on teacher leadership. Results also mirrored that teachers' expectations from teacher leadership roles differed significantly on institutional improvement and professional improvement subscales of teacher leadership according to gender variable while their perceptions differed significantly on institutional improvement subscale according to age variable and on institutional improvement and collaboration among colleagues subscales according to seniority variable. Results finally demonstrated that there were positive and significant relationships between teachers' perceptions on and expectations from teacher leadership roles. Several suggestions were presented in the light of research findings at the end of the study.
\end{abstract}

Keywords: Teacher leadership; Teacher leadership roles; High school; Teachers' perceptions; Teachers' expectations. 


\section{Extended Summary}

\section{Purpose}

This study sought to determine high school teachers' expectations from and perceptions on teacher leadership. The number of studies conducted on teacher leadership is quite limited (Beycioğlu ve Aslan, 2010, 2012; Can, 2009a, Can, 2009b) and this may increase the importance of the present study and its contribution to the related literature. Furthermore, several researches suggest that a new avenue of research is required for teacher leadership which constitutes a potential resource for school improvement and student engagement (Frost and Harris, 2003; Grant, 2006; Muijs and Harris, 2007; Zinn, 1997). Harris and Muijs (2005) argue that teacher leadership represents a different point of view for school leadership in that each member of school including academicals and others supports learning and teaching processes, and that relationships and interactions among school members are accepted as one of the fundamental factors of this kind of leadership. In this regard, this study aiming at finding out teachers' expectations from and perceptions on teacher leadership may constitute a rich database for policy makers about the improvement of teaching and learning in schools, composing more positive school climate, teacher collaboration, and relationship among school members. Thus, the purpose of this study was to determine high school teachers' expectations from and perceptions on teacher leadership and whether their perceptions and expectations change significantly according demographic variables such as gender, age, and seniority. This study also concentrates on correlations between high school teachers' expectations 
from and perceptions on teacher leadership.

\section{Methods}

This study used survey model for gathering data. A total of 291 teachers employed in 16 high schools in Kastamonu province participated in the study. The sample of this study consisted of $145(49.8 \%)$ males and $146(50.2 \%)$ females. More than half of the teachers (54\%) were between 21-30 years old. Moreover, 74 teachers (25.4\%) had 1-5 years of teaching experience while 103 teachers (35.4\%) had 11-15 years of teaching experience.

\section{Instrumentation}

Teacher Leadership Scale: This Likert-type scale responded on a rating scale from 1 to 5 was developed by Beycioğlu ve Aslan (2010). The scale has a total of 25 items categorized in three subscales entitled as "institutional improvement" (9 items), "professional improvement" (11 items), and "collaboration among colleagues" (5 items) measuring both the perceptions and expectations of teachers on teacher leadership. The total variance explained by 25 items for perception dimension was $57.23 \%$ and $51.60 \%$ for expectation dimension. Item-total correlations ranged from .47 to .92 for perception dimension and from .51 to .77 for expectation dimension. Furthermore, Cronbach's Alpha was computed as .93 for expectation and .95 for perception dimension. In this study, we computed Cronbach's Alpha for both expectation and perception dimensions, and it was found .93 for expectation and .88 for perception dimensions. Cronbach's Alpha coefficients computed for subscales of expectation and perception dimensions were as follows: .87 for insti- 
tutional improvement, .90 for professional improvement, and .77 for collaboration among colleagues in expectation dimensions; .85 for institutional improvement, .72 for professional improvement, and .80 for collaboration among colleagues in perception dimensions.

\section{Data Analysis}

The data of the study was analyzed by using arithmetic mean, standard deviation, t-test, one way ANOVA, and Pearson product-moment correlation coefficients. In order to determine whether there are significant differences between the mean scores of teachers in the expectation and perception dimensions of teacher leadership in terms of their gender, age, and seniority variables, independent samples t-test and one-way ANOVA were performed. Pearson product-moment correlation coefficients were also calculated to determine the relationships between teachers' expectations from and perceptions on teacher leadership.

\section{Results}

Results revealed that the level of high school teachers' expectations from teacher leadership was higher than the level of their perceptions on teacher leadership. Results also showed that high school teachers expectations from teacher leadership differed significantly in institutional improvement [ $\mathrm{t}(289)=4.11, \mathrm{p}<.05]$ and professional improvement [ $\mathrm{t}(289)=2.23, \mathrm{p}<.05]$ subscales according to gender variable while their expectations did not differ significantly in collaboration among colleagues subscale [ $\mathrm{t}(289)=-.41, \mathrm{p}>.05$ ] according to gender variable. Results also mirrored that participants' perceptions on 
institutional improvement subscale differed significantly $[\mathrm{F}(2,288)=5.70, \mathrm{p}<.05]$ according to age variable. Teachers' perceptions on institutional improvement $[\mathrm{F}(3.287)=4.99, \mathrm{p}<.05]$ and collaboration among colleagues $[\mathrm{F}(3.287)=3.16, \mathrm{p}<.05]$ subscales of teacher leadership also differed significantly according to seniority variable. Results also illustrated that there were positive and significant relationships between teachers' expectations from and perceptions on teacher leadership.

\section{Discussion}

The present study examined high school teachers' perceptions on and expectations from teacher leadership roles. This study supports the notion that demographic variables are associated with teacher leadership. However, the number of empirical studies concentrating on teachers' leadership roles is very limited and this becomes a potential obstacle to make a detailed discussion on research findings of the present study. Research findings point out the call for more detailed empirical studies on teacher leadership. Therefore, further studies should be carried out in different educational settings by using different research methods. It is also possible to say that more studies focusing on the organizational and personal factors affecting teachers' assuming leadership roles are needed.

\section{Giriş}

Liderlik alanyazınında okul liderliği kavramı hâlâ büyük oranda okul müdürünün liderliğiyle eş değer görülmekte ve yapılan çalışmalarda genellikle okul müdürlerine ve okul müdürlerinin liderlik stille- 
rine odaklanılmaktadır (Harris ve Muijs, 2005; Murphy, 2005). Buna karşın, geleneksel okul liderliği olarak ifade edilebilecek anlayışın, okul değişimi ve yenileşme süreçlerini olumsuz yönde etkilediği, öğretimin kalitesinin artırılmasını ve öğrenci öğrenmesinin üst düzeye çıkarılmasını sağlayacak iş birliği ve ortak sorumluluğa dayalı bir okul ortamının oluşturulmasına yeterince katkı sağlamadığı vurgulanmaktadır (Harris ve Lambert, 2003). Bu bağlamda, son yıllarda müdür odaklı geleneksel okul liderliği anlayışının okulun karmaşıklaşan doğası ve işleyişiyle örtüşmediği daha yüksek sesle dile getirilmeye başlanmış ve bütün okul üyelerinin ortak bir amaç ve sorumluluk duygusuyla sahipleneceği, daha paylaşımcı ve daha az merkeziyetçi liderlik yaklaşımları tartışmaya açılmıştır (Barth, 1990; Beycioğlu ve Aslan, 2012; Coleman, 2006; Conzemius ve O'Neill, 2001; Gronn, 2009; Harris, 2011; Lambert, 1998, 2003, 2005; Murphy, 2005; Sergiovanni, 2001, 2007; Spillane ve Healey, 2010; Walker, 2002). Bununla birlikte, okul müdürlerinin sorumluluklarının, iş yüklerinin ve sahip olmaları beklenen bilgi ve becerilerin giderek artmasının (Busher ve Harris, 1999; Hallinger, 2005), yeni bir okul liderliği anlayışının geliştirilmesine yönelik ihtiyacı daha da belirginleştirdiği ifade edilmektedir (Grubb ve Flessa, 2006).

Okul liderliğini formel otorite ile sınırlama eğiliminde olan geleneksel okul liderliğine karşı geliştirilen perspektiflerden biri öğretmen liderliğidir. Öğretmen liderliği, okul gelişimi ve öğrenci öğrenmesinin üst düzeyde sağlanabilmesi ve sürdürülebilirliği, okul ortam1nın iş birliği, ortak sorumluluk, değerler, paylaşılan vizyon, etkili 
meslekî gelişim ve yenileşme gibi hususlara yönelik duyarlılık kazanması ve okulda herkes için öğrenme ve öğretimin geliştirilmesi bağlamında özellikle 1990'lı yıllardan itibaren araştırılmaya başlanmış ve son yıllarda giderek daha fazla gündem bulmuş bir kavramdır (Beycioğlu ve Aslan, 2012; Can, 2009a; Camburn, Rowan ve Taylor, 2003; Frost ve Harris, 2003; Grant, 2006; Harris ve Lambert, 2003; Harris ve Muijs, 2003, 2005; Helterbran, 2010; Katzenmeyer ve Moller, 2009; Lambert, 2003; Leithwood ve Jantzi, 2000; Murphy, 2005).

Öğretmen liderliğinin geniş bir araştırma alanı bulmasıyla ilgili çeşitli argümanların mevcut olduğu görülmektedir. Barth (1990) artan beklenti ve taleplerle birlikte giderek daha karmaşı kurumlar hâline gelen okulların okul müdürleri tarafından yönetilmesinin zorlaştığını, bu nedenle okuldaki bütün bireylerin katkı sağlayacağı ve sorumluluk üstleneceği bir liderlik anlayışına ihtiyaç duyulduğunu ileri sürmektedir. Geleneksel liderlik anlayışının okul için geçerliliğini yitirdiğini belirten Fullan (1994), okulun başarılı olması için liderlerin farklı bireylerin bilgi, beceri ve uzmanlıklarından faydalanması ve okulu ortak sorumluluk anlayışıyla hareket eden bir kurum hâline getirmesi gerektiğini dile getirmektedir. Beachum ve Dentith (2004) ise okul müdürlerinin, öğretmenlerle iş birliği içinde ve demokratik bir anlayış çerçevesinde çalışabilecekleri bir okul ortamı yaratması gerektiğini belirtmektedir. Bu argümanlara paralel bir biçimde Lambert (2003), okulun tek bir kişi tarafından yönetildiği ve aynı zamanda okul süreçlerine ilişkin sorumluluğun çoğu zaman yalnızca okul müdürüne yüklendiği kahraman liderlik anlayışının sürdürülebilir bir okul gelişimi 
için yetersiz olduğunu vurgulamaktadır. Grant (2006) öğretmen liderliğinin öğretmenlere okul süreçlerine katılma ve katkı sağlama olanağını tanıdığını ve öğretmenlerin öğrenme ve öğretimin geliştirilmesi, okul vizyonunun belirlenmesi, ağbağlar kurma ve aile katılımı gibi okulun işleyişiyle yakından ilişkili süreçlere liderlik edebileceğini ileri sürmektedir. Öte yandan, öğretmen liderliği anlayışı çerçevesinde okul müdüründen de beklentiler farklılaşmaktadır. Katzenmeyer ve Moller (2009) okul müdürlerinin öğretmenlerin liderlik davranışlarının ortaya çıkarılmasında oldukça önemli rollere sahip olduklarını ve gösterecekleri liderlik davranışlarıyla öğretmenlerin liderlik potansiyellerini ortaya çıkarabileceklerini ifade etmektedir. Buckner ve McDowelle (2000) ise okul müdürlerinin, öğretmen liderliğinin önemini ve okul gelişimi sürecine katkılarını kavrayarak, öğretmen liderliğinin okulun bütün üyelerince kabul edileceği bir okul atmosferi oluşturarak ve öğretmenlerin mesleki gelişimlerini sürdürmeleri için onlara firsatlar yaratarak öğretmen liderliğinin gelişimini etkileyebileceğini belirtmektedir. Harris ve Muijs'in (2005) de ifade ettiği gibi öğretmen liderliği bütün öğretmenlerin liderlik yapabilecek bilgi, beceri ve uzmanlığa sahip olduğu ilkesinden hareket etmektedir. Bu bağlamda, öğretmen liderliğinin ortaya çıkış nedenlerinden birinin, öğrenci ihtiyaçlarına daha fazla cevap verebilmek ve okulu daha etkili bir biçimde yönetmek için okuldaki insan kaynağından optimum düzeyde faydalanmak olduğu ifade edilebilir.

Öğretmen liderliğinin ortaya çıkışında etkili olan bir diğer argüman, okuldaki insan kapasitesinin geliştirilmesidir. $\mathrm{Bu}$ durumun 
temel nedeninin, öğretimin ve öğrenci öğrenmesinin geliştirilmesinin öğretmenlerin bilgi, beceri ve yaptıkları işe olan bağlılıklarıyla yakından ilişkili bulunması olduğu söylenebilir (Newmann ve Wehlage, 1995). Öğretmen liderliği ve kapasite geliştirmeyi ilişkilendiren Crowther ve Olsen (1997), öğretmen liderliğinin öğretmenlerin okulun özellikle yönetsel boyutunda sorumluluk üstlenmelerini sağlamak amacıyla kapasitelerinin geliştirilmesine odaklandığını ileri sürmektedir.

Katzenmeyer ve Moller (2009), okul gelişimi ve öğrenci öğrenmesinin üst düzeye çıkarılması noktasında oldukça önemli bir rol oynayan öğretmenlerin meslekî gelişimlerinin etkili bir biçimde sağlanması düşüncesinin, öğretmen liderliğini ortaya çıkaran en önemli faktörlerden biri olduğunu vurgulamaktadır. Katzenmeyer ve Moller'a göre, öğretmen liderliğinin okulda etkin hâle getirilmesi, öğretmenlere meslekî gelişimlerinde yerinde yardım sağlayacak önemli bir potansiyelin açığa çıkarılması anlamına gelmektedir. Bununla birlikte, okul yöneticilerine okulda daha olumlu bir öğrenme ve öğretme ortamının oluşturulmasına ve öğrencilerin farklı yönlerden gelişimlerinin en üst düzeyde sağlanmasına yönelik yapılan baskıların, okul liderliği süreçlerine öğretmenlerin etkin bir biçimde katılımına zemin hazırladığ söylenebilir (Harris, Brown ve Abbott, 2006). Muijs ve Harris (2003) öğretmen liderliğinin iş birliği ve ortak sorumluluk anlayışına dayalı bir okul kültüründe öğretmenlerin meslekî gelişimini kolaylaştıracağını belirtmektedirler. Öte yandan, başka çalışmalarda öğretmen liderliğinin, okulun değişim ve dönüşüm kapasitesinin geliştirilmesi ve çağın gereklerine uygun bir biçimde işlevini sürdürebilmesi bağlamında 
tartış1lığ1 da görülmektedir (Frost, 2008; Harris ve Muijs, 2005; Lieberman ve Miller, 2005). Bu bağlamda, öğretmen liderliğinin önemli iddialarından birinin de okuldaki insan kaynağının gelişiminin sağlanması suretiyle değişim, dönüşüm, öğrenme ve öğretme süreçlerine ilişkin sahip olunan potansiyelin geliştirilmesi olduğu ileri sürülebilir.

\section{Öğretmen Liderliği}

Öğretmen liderliği, okulda öğrenme ve öğretimin geliştirilmesi sürecinde öğretmenlerin liderliklerinden faydalanılması ve koçluk, mentörlük, grup çalışmaları ve eylem araştırmaları gibi okulun teknik özüyle ilgili hususlarda öğretmenlerin bilgi, beceri ve uzmanlıklarının daha işlevsel hâle getirilmesi olarak nitelendirilebilir. Başka bir ifadeyle öğretmen liderlĭği, diğer öğretmenlerin meslekî gelişimlerinin etkili bir biçimde sürdürülmesi, okulda öğrenme ve öğretimin geliştirilmesi ve öğrenci öğrenmesine katk1 sağlayacak en iyi öğretim pratiklerinin belirlenip uygulanması sürecinde öğretmenlerin liderlik davranışlarından yararlanma anlayışı olarak değerlendirilmektedir (Harris ve Muijs, 2005).

Öğretmen liderliği, öğretmenlerin okulda değişim ve gelişim sürecine etkin bir şekilde katılmaları, ilgili süreçlere bilgi, beceri ve uzmanlıklarıyla katkı sağlamaları ve diğer öğretmenleri olumlu yönde etkilemeleri olarak ifade edilebilir (Wasley, 1991) (akt; Harris, 2003). Crowther ve Olsen (1997) öğretmen liderliğinin öğretmenlerin sınıf içi öğretim uygulamalarını geliştirirken aynı zamanda okulun yönetsel boyutunda görev ve sorumluluk almalarıyla ilişkili olduğunu savunmaktadır. Katzenmeyer ve Moller (2009) öğretmen liderliğini sınıf 
içinde ve dışında okul süreçlerine liderlik etme, sürekli öğrenme ve meslekî gelişimini sürdürme, meslektaşlarının mesleki gelişimine yardımcı olma, okulda öğrenme ve öğretime ilişkin tartışmaları yönlendirme ve öğrenci öğrenmesinin gelişmesini katkı sağlama olarak tanımlamaktadır. Can (2009a) öğretmen liderliğini öğretime yönelik en etkili sınıf içi öğretim uygulamaları belirlemek ve okul içi etkinliklerde çeşitli rolleri üstlenebilmek olarak ifade etmektedir. York-Barr ve Duke (2004) öğretmen liderliğini karar verme, plânlama, uygulama ve değerlendirme gibi okula ilişkin temel süreçlerde öğretmenlerin liderlik becerini ön plâna çıkarma olarak tanımlarken, Harris ve Lambert (2003) öğretmen liderliğinin temel işlevleri arasında okulda meslekî bir iş birliği ortamının sağlanmasını, örgütsel gelişim ve yenileşme süreçlerinin kolaylaştırılmasını ve örgütteki insan kapasitesinin geliştirilmesini saymaktadır.

\section{Öğretmen Liderlerden Beklenen Roller}

Harris ve Muijs (2005) öğretmen liderlerin öncelikle uzman birer öğretmen olduklarını, zamanlarının önemli bir kısmını sınıflarında geçirdiklerini ve uzmanlıklarına gereksinim duyulduğunda ise okul gelişimi ve yenileşme çabalarına katkıda bulunduklarını dile getirmektedirler. Leithwood (2003) öğretmen liderlerin okulda güçlü bir öğrenme kültürünün oluşturulmasında ve okulun dış bask1 ve tehditlere karşı dayanıklılığ korumasında önemli rollere sahip olduklarını ileri sürmektedir. Katzenmeyer ve Moller (2009) ve Can (2009a) öğretmen liderliğini tanımlarken sınıf içinde ve dışında liderlik etme, meslekî gelişimini devam ettirme, meslektaşlarının mesleki gelişimine yardımcı 
olma, okulda öğrenme ve öğretime ilişkin tartışmaları yönlendirme ve öğrenci öğrenmesinin gelişimine katkı sağlama gibi hususlara dikkat çekmektedirler. Bu tanımdan yola çıkarak öğretmen liderlerden öncelikli beklentinin, sınıf içi uygulamaları geliştirme ve öğrencilerine liderlik etme olduğu yönünde bir çıkarsama yapılabilir. Bununla birlikte, öğretmen liderlerin yalnızca kendilerinin değil, meslektaşlarının meslekî gelişimine katkı sağlayarak onları etkilemeye ve okulun öğrenen bir örgüt olarak kurgulanmasına yönelik çaba harcadıkları anlaş1lmaktadır.

Harris (2002) öğretmen liderlerin önemli rolleri arasında transfer ve aracılığa vurgu yapmaktadır. Transfer rolü, öğretmen liderlerin okul gelişimine yönelik ilkeleri sınıfa uyarlamaları ve öncelikle sınıflarının lideri olmalarıyla ilişkilidir. Katzenmeyer ve Moller'ın (2009) da öğretmen liderliği tanımına sınıf liderliği rolüyle başladığg düşünüldüğünde, öğretmen liderlerden beklentilerin öncelikle kendi sınıflarında gerçekleşen öğretimi ve öğrenci öğrenmesini geliştirme yönünde yoğunlaştığı ileri sürülebilir. Aracılık rolü, öğretmen liderlerin okulda öğretimin geliştirilmesi ve öğretmenler arasında öğretime yönelik iş birliğinin sağlanması anlamına gelmektedir (Harris, 2002). Fullan (2008) okul gelişimde en önemli unsurlardan birinin sınıf içinde yapılan öğretimin tartışılması ve iş birliğgine dayalı bir anlayışla geliştirilmesi olduğunu belirtmektedir. Bu bağlamda, öğretmen liderlerin okul gelişimi ve öğrenci öğrenmesinin artırılması bağlamında aracılık rollerini başarıyla yerine getirmeleri önemli görülebilir.

Harris (2002) öğretmen liderlerden diğer beklentilerin, liderliğin 
okulun farklı üyeleri tarafından sahiplenilmesini sağlama; bilgi, beceri ve tecrübeleri ile okul gelişimi sürecine katkı sağlama ve okulda öğrenme ve öğretim süreçlerinin sağlıklı bir şekilde yönetilebilmesi için okul üyeleri arasında kurulacak yakın ilişkileri düzenleme noktasında yoğunlaştığını ifade etmektedir. Başka bir çalışmada, öğretmen liderlerden okulun daha çok psikolojik boyutunun iyileştirilmesi bağlamında ele alınabilecek meslektaşlar arasında güven ve samimiyet odaklı ilişkilerin geliştirilmesine yönelik birtakım beklentilerin olduğu vurgulanmaktadır (Lieberman, Saxl ve Miles, 2000). Bu bağlamda, öğretmen liderlerden sınıflarının dışında okul gelişim süreçlerine katkı sağlamaları, meslektaşlarını okul amaçları doğrultusunda etkilemeleri ve liderlik sürecindeki sorumluluğu paylaşmak üzere onları motive etmeleri gibi beklentilerin olduğu söylenebilir.

Öğretmen liderlerin okul kültürünün şekillenmesinde önemli rolleri olduğunu belirten Fullan (1994), öğretmen liderlerin öğrenme ve öğretme, bireyler arası ilişkiler, sürekli mesleki öğrenme, değişim yönetimi ve örgütsel değerler bağlamında sergileyecekleri liderlik davranışlarıyla okul kültürünü etkileyebileceklerini ileri sürmektedir. Gehrke (1991) öğretmen liderlerden beklenen rolleri şu şekilde özetlemektedir: (1) Sınıflarında kullandıkları öğretim uygulamalarını sürekli olarak geliştirme, (2) okul gelişimine yönelik gerçekleştirilen uygulamaları organize etme, (3) müfredâtın geliştirilmesi sürecine bilgi ve becerileriyle katkı sağlama, (4) okulda karar verme süreçlerine etkin bir biçimde katılma, (5) meslektaşlarının meslekî gelişimlerine yardımcı olma, (6) öğretmen performansının değerlendirilmesi süreçlerine 
katılma.

$\mathrm{Bu}$ araştırmada, ortaöğretim okullarında görev yapan öğretmenlerin öğretmen liderliğine ilişkin algı ve beklentileri ortaya çıkarılmaya çalışılmıştır. Öğretmen liderliğine ilişkin yapılan çalışmaların oldukça sınırlı olmasının ve özellikle Türkiye'de konuya ilişkin gerçekleştirilen ampirik çalışmaların oldukça sınırlı olmasının (Beycioğlu ve Aslan, 2010, 2012; Can, 2009a, Can, 2009b), öğretmen liderliğine ilişkin alg1 ve beklentileri ortaya koyması beklenen mevcut çalışmanın önemini ve alana sağlayacağı katkıyı artırdığı düşünülmektedir. Ayrıca, okul gelişimi ve öğrenci öğrenmesine yönelik potansiyel bir güç olarak kabul edilen öğretmen liderliğine ilişkin daha fazla araştırma bulgusuna ihtiyaç duyulduğu vurgulanmaktadır (Beycioğlu ve Aslan, 2012; Frost ve Harris, 2003; Grant, 2006; Muijs ve Harris, 2007; Zinn, 1997). Harris ve Muijs (2005) öğretmen liderliğinin, okulda öğretme ve öğrenme süreçlerinin okulun öğretimle ilgili olan ya da olmayan tüm üyeleri tarafından desteklediği ve okul üyeleri arasında gerçekleşen ilişki ve etkileşimlerin liderlik sürecinin temel belirleyicilerinden biri olarak kabul edildiği bir liderlik anlayışını temsil ettiğini belirtmektedir. $\mathrm{Bu}$ bağlamda, öğretmen liderliğine ilişkin öğretmenlerin alg1 ve beklentilerini ortaya koymaya çalışan bu çalışmanın, okulda öğrenme ve öğretme ortamının geliştirilmesine, daha olumlu bir okul iklimi oluşturulmasına, öğretmen iş birliğine ve öğretmenler arasındaki ilişkilere yönelik politika yapıcılar için önemli bir veri kaynağı teşkil edebileceği düşünülmektedir. Mevcut araştırmada ortaöğretim okullarında görev yapan öğretmenlerin öğretmen liderliğine ilişkin alg1 ve beklentileri 
belirlenmeye çalışılarak öğretmen liderliğinin ne düzeyde sergilendiği ve öğretmen liderliğine ilişkin beklentilerin neler olduğu tespit edilmeye çalışılmıştır. Bununla birlikte, öğretmenlerin öğretmen liderliğine ilişkin algı ve beklentilerinin cinsiyet, yaş ve meslekî kıdem değişkenlerine göre anlamlı bir şekilde farklılaşıp farklılaşmadığı incelenmiştir. Araştırmada son olarak öğretmenlerin öğretmen liderliğinin alt boyutlarına (kurumsal gelişme, meslekî gelişim, meslektaşlarla iş birliği) ilişskin algı ve beklentileri arasındaki ilişkiler incelenmiştir.

\section{Yöntem}

\section{Araştırmanın Modeli}

$\mathrm{Bu}$ araştırma, ilişkisel tarama modelindedir. İlişkisel tarama modeli, iki veya daha fazla değişken arasında birlikte değişim varlığını veya derecesini belirlemeyi amaçlayan araştırma modelidir (Karasar, 1999).

\section{Evren ve Örneklem}

Araştırmanın evrenini Kastamonu il merkezinde görev yapan öğretmenler oluşturmaktadır. $\mathrm{Bu}$ evrenden basit seçkisiz örnekleme yoluyla 16 ortaöğretim okulundan seçilen toplam 291 öğretmen araştırmaya katılmıştır. Bu öğretmenlerin 145'i (\% 49.8) erkek, 146's1 (\% 50.2) kadındır. Araştırmaya katılan öğretmenlerin 82'si (\% 28.2) 21-30, 157'si (\% 54) 31-40 ve 52'si (17.9) 41 ve üzeri yaş grubundadır. Meslekî kıdem değişkenine göre incelendiğinde, öğretmenlerin 74'ünün (\% 25.4) 1-5, 69'unun (\% 23.7) 6-10, 103 'ünün (\% 35.4) 11-15 ve 45'inin (\% 15.5) 16 yıl ve üzeri kıdeme meslekî kıdeme sahip olduğu belirlenmiştir. 


\section{Veri Toplama Araçları}

Araştırmanın veri toplama aracı üç bölümden oluşmaktadır. Birinci bölümde orta öğretim okulu öğretmenlerinin cinsiyet, yaş ve meslekî kıdem gibi demografik değişkenlerine ilişkin bilgiler yer almaktadır. İkinci bölümde ise katılımcıların öğretmen liderliğine ilişkin alg1 ve beklentilerini belirlemek amacıyla "Öğretmen Liderliği Ölçeği" sunulmuştur.

Öğretmen Liderliği Ölçeği: Beycioğlu ve Aslan (2010) tarafindan geliştirilen Likert tipi bu ölçek, "Her zaman=5 ve Hiçbir zaman=1" arasında değişen bir aralıkta puanlanmaktadır. Ölçekte yer alan maddeler hem algı hem de beklenti açısından üç boyutta toplanmaktadır. Kurumsal gelişme, mesleki gelişim ve meslektaşlarla iş birliği olarak isimlendirilen üç boyutta toplam 25 madde bulunmaktadır. Kurumsal gelişme boyutunda 9 (örnek madde: "Ill, bölge veya ülke düzeyindeki mesleki çalışma gruplarında görev almak"), meslekî gelişim boyutunda 11 (örnek madde: "Meslektaşlarıyla, öğrencilerin sınıf düzeyinde başarı durumlarıyla ilgili görüş alış verişinde bulunmak") ve meslektaşlarla iş birliği boyutunda 5 (örnek madde: "Okulla ilişkin sorunların çözümüne yönelik olarak "katılımcı" tutumlar sergilemek") madde yer almaktadır. Toplamda 25 maddeden oluşan ölçeğin açıkladığı toplam varyans algı boyutu için \% 57.23 ve beklenti boyutu için \% 51.60'tır. Ölçeğin madde toplam korelasyonları ise algı için .47 ile .92 ve beklenti için .51 ile .77 arasında değişmektedir. Beycioğlu ve Aslan (2010) ölçeğin güvenirliğini Cronbach Alpha katsayısı ve test-tekrar test yöntemleriyle test etmişlerdir. Buna göre, hesaplanan Cronbach Alpha 
iç tutarlık katsayısı beklenti için .93 ve algı için .95 olarak hesaplanmıştır. Beklentiye ait boyutlarda Cronbach Alpha iç tutarlık katsayıları kurumsal gelişme için .79, mesleki gelişim için .86 ve meslektaşlarla iş birliği için .89 olarak bulunmuştur. Algıya ait boyutlarda ise Cronbach Alpha iç tutarlık katsayıları kurumsal gelişme için .87, mesleki gelişim için .87 ve meslektaşlarla iş birliği için .92 'dir. Ayrıca, araştırmacılar öğretmen ve yöneticilerden oluşan bir gruba farklı zamanlarda iki uygulama yapmış ve her iki uygulamada elde edilen puanlar arasındaki Pearson Momentler Çarpım Korelasyon katsayısını hesaplamışlardır. Buna göre beklenti ( $\mathrm{r}=.80)$ ve algı boyutu $(\mathrm{r}=.87)$ için yapılan hesaplamalar ölçeğin güvenilir olduğunu göstermektedir.

Araştırma kapsamında, Öğretmen Liderliği Ölçeği'nin güvenirliği belirlemek amacıyla Cronbach Alpha katsayısı hesaplanmıştır. Buna göre, hesaplanan Cronbach Alpha iç tutarlık katsayısı beklenti için .93 ve algı için .88 olarak hesaplanmıştır. Beklentiye ait boyutlarda Cronbach Alpha iç tutarlık katsayıları kurumsal gelişme için .87, mesleki gelişim için .90, meslektaşlarla iş birliği için .77 olarak bulunmuştur. Algıya ait boyutlarda ise Cronbach Alpha iç tutarlık katsayıları kurumsal gelişme için .85, mesleki gelişim için .72 ve meslektaşlarla iş birliği için .80'dir.

\section{Verilerin Toplanması ve Analizi}

Araştırma verileri SPSS 15.0 programı kullanılarak analiz edilmiştir. Veriler analiz edilmeden önce veri seti incelenmiş, eksik değerlere EM Algoritması yoluyla değer ataması yapılmıştır. Araştırmanın alt problemlerinin çözümlenmesi sürecinde öncelikle ölçeğin her 
bir alt boyutunda bulunan maddelerin aritmetik ortalama değerleri hesaplanmış ve analizler bu faktör değerleri üzerinden gerçekleştirilmiştir. Ortaöğretim okulu öğretmenlerinin öğretmen liderliğine ilişkin alg1 ve beklentilerinin cinsiyet değişkenine göre farklılığının analizinde bağımsız gruplar için t-testi; yaş ve mesleki kıdem değişkenlerine göre farklılığın analizinde tek yönlü varyans analizi (ANOVA) yapılmıştır. Öğretmen liderliğine ilişkin öğretmenlerin algı ve beklentileri arasındaki ilişkiyi tespit etmek için ise Pearson momentler çarpım korelasyon katsayıları hesaplanmıştır. Analizlerde hata payı .05 olarak alınmıştır.

\section{Bulgular ve Yorum}

\section{Katılımcıların Öğretmen Liderliği Rollerine İlişkin Beklentileri}

Araştırmaya katılan ortaöğretim okulu öğretmenlerinin öğretmen liderliğine ilişkin beklentileri Tablo 1'de verilmiştir.

Tablo 1. Katılımcıların Öğretmen Liderliğine İlişkin Beklentileri

\begin{tabular}{lcc}
\hline Değişkenler & $\bar{x}$ & $S$ \\
\hline Öğretmen liderliği & & \\
Kurumsal gelişme & 3.89 & .76 \\
Mesleki gelişim & 4.39 & .60 \\
Meslektaşlarla iş birliği & 4.31 & .67 \\
\hline
\end{tabular}

Tablo 1 incelendiğinde, ortaöğretim okulu öğretmenlerinin öğretmen liderliğine ilişkin beklentilerinin yüksek olduğu görülmektedir. Bununla birlikte, katılımcıların en yüksek değeri meslekî gelişim $(\bar{X}$ $=.4 .39)$, en düşük değeri ise kurumsal gelişme $(\bar{X}=3,89)$ boyutuna verdikleri görülmektedir. 


\section{Katılımcıların Öğretmen Liderliği Rollerine İlişkin Algıları}

Araştırmaya katılan ortaöğretim okulu öğretmenlerinin öğretmen liderliğine ilişkin algıları Tablo 2'de verilmiştir.

Tablo 2. Katılımcıların Öğretmen Liderliğine İlişkin Algıları

\begin{tabular}{lcc}
\hline Değişkenler & $\overline{\mathrm{X}}$ & $S$ \\
\hline Öğretmen liderliği & & \\
Kurumsal gelişme & 3.29 & .75 \\
Mesleki gelişim & 4.01 & .83 \\
Meslektaşlarla iş birliği & 3.73 & .70 \\
\hline
\end{tabular}

Tablo 2'ye göre, katılımcıların öğretmen liderliğine ilişkin alg1larının beklentilerine göre daha düşük düzeyde olduğu anlaşılmaktadır. Bununla birlikte, katılımcıların algı boyutunda en düşük değeri kurumsal gelişme $(\bar{X}=3.29)$ boyutuna verdikleri görülmektedir. Başka bir anlatımla katılımcılar, öğretmen liderliğinin kurumsal gelişme boyutu kapsamındaki davranışları daha az sergilemektedirler.

\section{Katılımcıların Öğretmen Liderliğine İlişkin Beklentilerinin Cin- siyete Göre Karşılaştırılması}

Araştırmaya katılan ortaöğretim okulu öğretmenlerinin öğretmen liderliğine ilişkin beklenti düzeylerinde cinsiyete göre farkın anlamlı olup olmadığını belirlemek amacıyla t-testi yapılmış ve sonuçlar Tablo 3 'te verilmiştir. 
Tablo 3. Katılımcıların Öğretmen Liderliğine İlişkin Beklentilerinin Cinsiyete Göre T-Testi Sonuçları

\begin{tabular}{lcccccc}
\hline \multirow{2}{*}{ Değişkenler } & \multicolumn{2}{c}{ Erkek $(n=145)$} & \multicolumn{2}{c}{ Kadın $(n=146)$} & \multirow{2}{*}{$t$} & \\
\cline { 2 - 5 } & $\bar{X}$ & $S$ & $\bar{X}$ & \multicolumn{1}{c}{$S$} & & \\
\hline Kurumsal gelişme & 3.71 & .78 & 4.06 & .69 & 4.11 & .00 \\
Mesleki gelişim & 4.31 & .68 & 4.47 & .50 & 2.23 & .03 \\
Meslektaşlarla iş birliği & 4.33 & .64 & 4.29 & .72 & -.41 & .68 \\
\hline
\end{tabular}

Tablo 3 incelendiğinde, ortaöğretim okulu öğretmenlerinin öğretmen liderliğine ilişkin beklenti ortalamalarının cinsiyet değişkenine göre kurumsal gelişme $[t(289)=4.11, p<.05]$ ve meslekî gelişim $[t$ $(289)=2,23, p<.05$ ] boyutlarında anlamlı bir biçimde farklılaştığı tespit edilmiştir. Meslektaşlarla iş birliği boyutunda ise öğretmenlerin beklenti düzeylerinde cinsiyet değişkenine göre anlamlı bir farklılığın olmadığ1 [ $t$ (289)=-.41, $p>.05]$ görülmektedir.

\section{Katılımcıların Öğretmen Liderliğine İlişkin Algılarının Cinsiyete Göre Karşılaştırılması}

Araştırmaya katılan ortaöğretim okulu öğretmenlerinin öğretmen liderliğine ilişkin algı düzeylerinde cinsiyete göre farkın anlamlı olup olmadığını belirlemek amacı ile t-testi yapılmış ve sonuçlar Tablo 4'te verilmiştir.

Tablo 4. Katılımcıların Öğretmen Liderliğine İlişkin Algılarının Cinsiyete Göre T-Testi Sonuçları 


\begin{tabular}{|c|c|c|c|c|c|c|}
\hline \multirow[t]{2}{*}{ Değişkenler } & \multicolumn{3}{|c|}{$\begin{array}{l}\text { Erkek } \\
(n=145)\end{array}$} & \multirow{2}{*}{$\begin{array}{l}\text { Kadın } \\
(n=146) \\
S\end{array}$} & \multirow[t]{2}{*}{$t$} & \multirow[t]{2}{*}{$p$} \\
\hline & $\bar{X}$ & $S$ & $\bar{x}$ & & & \\
\hline Kurumsal gelişme & 3.22 & .80 & 3.37 & .70 & 1.71 & .09 \\
\hline Mesleki gelişim & 3.98 & .80 & 4.05 & .63 & .89 & .38 \\
\hline $\begin{array}{l}\text { Meslektaşlarla iş } \\
\text { birliği }\end{array}$ & 3.69 & .81 & 3.76 & .72 & .82 & .41 \\
\hline
\end{tabular}

Tablo 4 incelendiğinde, ortaöğretim okulu öğretmenlerinin öğretmen liderliğine ilişkin algılarının cinsiyet değişkenine göre kurumsal gelişme $[t(289)=1,71, p>.05]$, meslekî gelişim $[t(289)=.89, p>.05]$ ve meslektaşlarla iş birliği [t(289) $=.82, p>.05]$ boyutlarında anlamlı bir biçimde farklılaşmadığı görülmektedir. Başka bir anlatımla, erkek ve kadın öğretmenlerin liderlik rollerine ilişkin algıları benzerlik göstermektedir.

\section{Katılımcıların Öğretmen Liderliğine İlişkin Beklentilerinin Yaşa Göre Karşılaştırılması}

Araştırmaya katılan ortaöğretim okulu öğretmenlerinin öğretmen liderliğine ilişkin beklenti düzeylerinde yaşa göre farkın anlamlı olup olmadığını belirlemek amacı ile tek yönlü varyans analizi (ANOVA) yapılmış ve sonuçlar Tablo 5'te verilmiştir.

Tablo 5. Katılımcıların Öğretmen Liderliğine İlişkin Beklentilerinin Yaşa Göre ANOVA Sonuçları 


\begin{tabular}{|c|c|c|c|c|c|c|c|c|}
\hline \multirow[t]{2}{*}{ Değişkenler } & \multicolumn{2}{|c|}{$\begin{array}{c}21-30 \\
(n=82)\end{array}$} & \multicolumn{2}{|c|}{$\begin{array}{c}31-40 \\
(n=157)\end{array}$} & \multicolumn{2}{|c|}{$\begin{array}{c}41 \text { ve üzeri } \\
(n=52)\end{array}$} & \multirow[t]{2}{*}{$F$} & \multirow[t]{2}{*}{$p$} \\
\hline & $\overline{\bar{X}}$ & $S$ & $\bar{x}$ & $S$ & $\overline{\bar{X}}$ & $S$ & & \\
\hline Kurumsal gelişme & 3.93 & .70 & .87 & .73 & 3.89 & .93 & .18 & .83 \\
\hline Mesleki gelişim & 4.34 & .53 & 4.40 & .59 & 4.44 & .74 & .48 & .62 \\
\hline Meslektaşlarla iş birliğj & 4.30 & .66 & 4.36 & .63 & 4.19 & .80 & 1.16 & .32 \\
\hline
\end{tabular}

Tablo 5 incelendiğinde, ortaöğretim okulu öğretmenlerinin öğretmen liderliğine ilişkin beklentilerinin kurumsal gelişme $[F$ $(2,288)=.18, p>.05]$, mesleki gelişim $[F(2,288)=.48, p>.05]$ ve meslektaşlarla iş birliği $[F(2,288)=1.16, p>.05]$ boyutlarında yaşlarına bağlı olarak anlamlı bir biçimde farklılaşmadığı görülmektedir. Başka bir anlatımla, farklı yaş gruplarından öğretmenler liderlik rollerine ilişsin benzer beklentilere sahiptirler.

\section{Katılımcıların Öğretmen Liderliğine İlişkin Algılarının Yaşa Göre Karşılaştırılması}

Araştırmaya katılan ortaöğretim okulu öğretmenlerinin öğretmen liderliğine ilişkin algı düzeylerinde yaşa göre farkın anlamlı olup olmadığını belirlemek amacıyla tek yönlü varyans analizi (ANOVA) yapılmış ve sonuçlar Tablo 6'da verilmiştir.

Tablo 6. Katılımcıların Öğretmen Liderliğine İlişkin Algılarının Yaşa Göre ANOVA Sonuçları 


\begin{tabular}{lccccccccc}
\hline \multirow{2}{*}{ Değişkenler } & \multicolumn{2}{c}{$\begin{array}{c}21-30 \\
(n=82)\end{array}$} & \multicolumn{2}{c}{$\begin{array}{c}31-40 \\
(n=157)\end{array}$} & $\begin{array}{c}\text { 41 ve üzeri } \\
(n=52)\end{array}$ & $F$ & $p$ \\
\cline { 2 - 6 } & $\overline{\mathrm{X}}$ & $S$ & $\overline{\mathrm{X}}$ & $S$ & $\overline{\mathrm{X}}$ & $S$ & & \\
\hline Kurumsal gelişme & 3.45 & .73 & .16 & .75 & 3.45 & .75 & 5.70 & .00 \\
Mesleki gelişim & 3.97 & .75 & 3.97 & .75 & 4.21 & .61 & 2.52 & .08 \\
Meslektaşlarla iş & 3.78 & .70 & 3.70 & .80 & 3.72 & .77 & .28 & .76 \\
birliği & & & & & & & & \\
\hline
\end{tabular}

Tablo 6 incelendiğinde, ortaöğretim okulu öğretmenlerinin öğretmen liderliğine ilişkin algılarının yaş değişkenine göre mesleki ge$\operatorname{lişim~}[F(2.288)=2.52, p>.05]$ ve meslektaşlarla iş birliği $[F(2,288)=.28$, $p>.05$ ] boyutlarında anlamlı bir biçimde farklılaşmadığı görülmektedir. Bununla birlikte, katılımcıların öğretmen liderliğinin kurumsal gelişme boyutuna ilişkin algılarının yaş değișkenine göre anlamlı bir biçimde farklılaştı̆g ortaya konmuştur $[F(2,288)=5,70, p<.05]$. Kurumsal gelişme boyutunda ortaya konan algı farklılıklarının hangi yaş grupları arasında gerçekleştiğini belirlemek amacıyla yapılan Tukey testi sonuçları ise anlamlı farklılıkların 21-30 yaş grubundaki öğretmenlerle 31-40 yaş arası öğretmenler arasında 21-30 yaş grubu öğretmenlerin lehine; 31-40 yaş arası öğretmenlerle 41 yaş ve üzeri öğretmenler arasında da 41 yaş ve üzeri öğretmenlerin lehine gerçekleştiğini göstermektedir. Diğer bir ifadeyle, 21-30 yaş arasında ve 41 yaş ve üzerinde bulunan öğretmenlerin liderlik rollerine ilişkin algıları 31-40 yaş arasında bulunan öğretmenlerin algılarından anlamlı bir biçimde daha yüksektir. 


\section{Katılımcıların Öğretmen Liderliğine İlişkin Beklentilerinin Mes- lekî Kıdeme Göre Karşılaştırılması}

Araştırmaya katılan ortaöğretim okulu öğretmenlerinin öğretmen liderliğine ilişkin beklenti düzeylerinde meslekî kıdeme göre farkın anlamlı olup olmadığını belirlemek amacı ile tek yönlü varyans analizi (ANOVA) yapılmış ve sonuçlar Tablo 7'de verilmiştir.

Tablo 7. Katılımcıların Öğretmen Liderliğine İlişkin Beklentilerinin Mesleki Kıdeme Göre ANOVA Sonuçları

\begin{tabular}{|c|c|c|c|c|c|c|c|c|c|c|}
\hline \multirow[t]{2}{*}{ Değişkenler } & \multicolumn{2}{|c|}{$\begin{array}{c}1-5 \text { y1l } \\
(n=74)\end{array}$} & \multicolumn{2}{|c|}{$\begin{array}{l}6-10 \text { y1l } \\
(n=69)\end{array}$} & \multicolumn{2}{|c|}{$\begin{array}{c}11-15 \\
(n=103)\end{array}$} & \multicolumn{2}{|c|}{$\begin{array}{c}21 \text { ve } \\
\text { üzeri } \\
(n=45)\end{array}$} & \multirow[t]{2}{*}{$F$} & \multirow[t]{2}{*}{$p$} \\
\hline & $\bar{X}$ & $S$ & $\bar{X}$ & $S$ & $\bar{X}$ & $S$ & $\overline{\bar{X}}$ & $S$ & & \\
\hline Kurumsal gelişme & 3.99 & 73 & 3.84 & .68 & 3.83 & .75 & 3.92 & .92 & .83 & .48 \\
\hline Mesleki gelişim & 4.32 & 62 & 4.35 & .52 & 4.42 & .65 & 4.50 & .57 & .98 & .40 \\
\hline Meslektaşlarla iş birlie & i4.31 & 62 & 4.38 & .64 & 4.31 & .71 & 4.21 & .73 & .56 & .64 \\
\hline
\end{tabular}

Tablo 7 incelendiğinde, ortaöğretim okulu öğretmenlerinin öğretmen liderliğine ilişkin beklentilerinin meslekî kıdem değişkenine göre kurumsal gelişme $[F(3.287)=.83, p>.05]$, meslekî gelişim $[F(3,287)=.98, p>.05]$ ve meslektaşlarla iş birliği $[F(3.287)=.56, p>.05]$ boyutlarında anlamlı bir biçimde farklılaşmadığ 1 görülmektedir. Başka bir ifadeyle, farklı kıdem gruplarından öğretmenlerin öğretmen liderliğinin alt boyutlarına ilişskin beklenti düzeyleri benzerlik göstermektedir. 


\section{Katılımcıların Öğretmen Liderliğine İlişkin Algılarının Meslekî Kıdeme Göre Karşılaştırılması}

Araştırmaya katılan ortaöğretim okulu öğretmenlerinin öğretmen liderliğine ilişkin algı düzeylerinde meslekî kıdeme göre farkın anlamlı olup olmadığını belirlemek amacı ile tek yönlü varyans analizi (ANOVA) yapılmış ve sonuçlar Tablo 8'de verilmiştir.

Tablo 8. Katılımcıların Öğretmen Liderliğine İlişkin Algılarının Mesleki Kıdeme Göre ANOVA Sonuçları

\begin{tabular}{|c|c|c|c|c|c|c|c|c|c|c|}
\hline \multirow[t]{2}{*}{ Değişkenler } & \multicolumn{2}{|c|}{$\begin{array}{c}1-5 \text { y1l } \\
(n=74)\end{array}$} & \multicolumn{2}{|c|}{$\begin{array}{l}6-10 \text { y1l } \\
(n=69)\end{array}$} & \multicolumn{2}{|c|}{$\begin{array}{c}11-15 \\
(n=103)\end{array}$} & \multicolumn{2}{|c|}{$\begin{array}{c}21 \text { ve üzeri } \\
(n=45)\end{array}$} & \multirow[t]{2}{*}{$F$} & \multirow[t]{2}{*}{$p$} \\
\hline & $\bar{x}$ & $S$ & $\overline{\bar{X}}$ & $S$ & $\bar{x}$ & $S$ & $\bar{x}$ & $S$ & & \\
\hline Kurumsal gelişme & 3.54 & .68 & 3.09 & .70 & 3.22 & .72 & 3.36 & .91 & 4.99 & .00 \\
\hline Mesleki gelişim & 3.99 & .73 & 3.90 & .63 & 4.04 & .74 & 4.17 & .65 & 1.37 & .25 \\
\hline Meslektaşlarla iş birliği & 3.84 & .60 & 3.50 & .80 & 3.82 & .81 & 3.68 & .91 & 3.16 & .03 \\
\hline
\end{tabular}

Tablo 8 incelendiğinde, ortaöğretim okulu öğretmenlerinin öğretmen liderliğine ilişkin algılarının meslekî kıdem değişkenine göre kurumsal gelişme $[F(3.287)=4.99, p<.05]$ ve meslektaşlarla iş birliği $[F(3.287)=3.16, p<.05]$ boyutlarında anlamlı bir biçimde farklılaştığı, mesleki gelişim boyutunda $[F(3.287)=1.37, p>.05]$ ise anlamlı bir farklılığın ortaya çıkmadığı görülmektedir. Diğer bir deyişle, çeşitli k1dem gruplarından öğretmenlerin öğretmen liderliğinin kurumsal gelişme ve meslektaşlarla iş birliği boyutlarına yönelik algıları birbirinden farklıdır. Kurumsal gelişme ve meslektaşlarla iş birliği boyutlarında ortaya çıkan algı farklılıklarının hangi kıdem grupları arasında gerçekleştiğini belirlemek amacıyla yapılan Tukey testi sonuçları, 
meslektaşlarla iş birliği boyutunda 1-5 yıl kıdeme sahip olan öğretmenlerle 6-10 yıl kıdeme sahip olan öğretmen arasında 1-5 yıl kıdeme sahip olanların lehine ve 6-10 y1l k1deme sahip olanlarla 11-15 y1l k1deme sahip olanlar arasında 11-15 yıl k1deme sahip olanların lehine anlamlı farklılıkların oluştuğunu göstermektedir. Bununla birlikte, kurumsal gelişme boyutunda anlamlı farklılıkların 1-5 yıl kıdeme sahip olan öğretmenlerle 6-10 ve 11-15 y1l kıdeme sahip olan öğretmenler arasında 1-5 yıl kıdeme sahip olanların lehine oluştuğu tespit edilmiştir.

\section{Katılımcıların Öğretmen Liderliğine İlişkin Beklenti ve Algıları Arasındaki İlişki}

Araştırmaya katılan ortaöğretim okulu öğretmenlerinin öğretmen liderliğine ilişkin alg1 ve beklentileri arasındaki ilişkinin ortaya konması amacıyla Pearson Momentler Çarpım Korelasyon Katsayıları hesaplanmış ve sonuçlar Tablo 9'da verilmiştir.

Tablo 9. Katılımcıların Öğretmen Liderliğine İlişkin Beklentileri ve Algıları Arasındaki İlişki

\begin{tabular}{lcccccc}
\hline Değişkenler & 1 & 2 & 3 & 4 & 5 & 6 \\
\hline 1. Kurumsal gelişme (B) & - & $.63^{* *}$ & $.63^{* *}$ & $.47^{* *}$ & $.34^{* *}$ & $.22^{* *}$ \\
2. Mesleki gelişim (B) & & - & $.53^{* *}$ & $.27^{* *}$ & $.51^{* *}$ & $.28^{* *}$ \\
3. Meslektaşlarla iş birliği (B) & & & - & $.31^{* *}$ & $.33^{* *}$ & $.51^{* *}$ \\
4. Kurumsal gelişme (A) & & & - & $.62^{* *}$ & $.63^{* *}$ \\
5. Mesleki gelişim (A) & & & & - & $.62^{* *}$ \\
6. Meslektaşlarla iş birliği (A) & & & & & - \\
\hline
\end{tabular}

$$
\mathrm{A}=\mathrm{Alg} 1 \quad \mathrm{~B}=\text { Beklenti }
$$

Tablo 9 incelendiğinde, katılımcıların öğretmen liderliğinin alt boyutlarına yönelik beklenti ve algıları arasında orta düzeyde pozitif 
yönde anlamlı ilişkilerin olduğu görülmektedir. Bununla birlikte, kat1lımcıların öğretmen liderliğine ilişkin algı ve beklentileri arasında pozitif yönde en yüksek ilişkinin meslekî gelişim $(r=.51, p<.05)$ ve meslektaşlarla iş birliği $(r=.51, p<.05)$ boyutlarında görüldüğü söylenebilir. Alg1 ve beklenti arasındaki pozitif yönlü en düşük ilişkinin ise kurumsal gelişme ve meslektaşlarla iş birliği boyutunda $(r=.22, p<.05)$ gerçekleştiği görülmektedir.

\section{Tartışma, Sonuç ve Öneriler}

$\mathrm{Bu}$ araştırmada ortaöğretim okullarında görev yapan öğretmenlerin öğretmen liderliği rollerine ilişkin algı ve beklentileri cinsiyet, yaş ve meslekî kıdem değişkenleri açısından incelenmiştir. Bununla birlikte, öğretmenlerin liderlik rollerine ilişkin beklenti ve algıları arasındaki ilişkiler ortaya konmaya çalışılmıştır.

Araştırma sonuçları, öğretmenlerin liderlik rollerine ilişkin beklenti düzeylerinin algı düzeylerinden yüksek olduğunu göstermektedir. Bu bulgu ile Beycioğlu ve Aslan'ın (2012) araştırma bulguları benzerlik göstermektedir. Ayrıca, araştırmanın bu bulgusunun Can'ın (2009b) öğretmenlerin öğrenme ve kendilerini geliştirme isteklerinin yüksek, fakat bu yönde davranış gösterme sıklıklarının düşük olduğunu ortaya koyan araştırma bulgularıyla benzerlik gösterdiği söylenebilir. Bununla birlikte, katılımcıların öğretmen liderliğinin özellikle meslekî gelişim ve meslektaşlarla iş birliği boyutlarına ilişkin beklentilerinin oldukça yüksek olduğu görülmektedir. Bu bulgu, öğretmenlerin meslekî gelişimlerini sürdürme ve meslektaşlarıyla iş birliği içinde çalışma noktasında istekli oldukları anlamına gelebilir. Katılımcıların öğretmen li- 
derliğine ilişkin beklenti düzeylerinin algı düzeylerinden yüksek olması, öğretmenlerin liderlik rolleri sergilemeleri için yeterli firsatı sahip olamadıkları biçiminde de yorumlanabilir. İlgili alanyazın incelendiğinde, okulun örgütsel yapısının (Katzenmeyer ve Moller, 2009), okul üyelerinin rol algılarının (Frost ve Harris, 2003), okul müdürünün benimsediği liderlik anlayışının (DuFour, Eaker ve DuFour, 2005), zaman faktörünün (Zinn, 1997), örgütte bireyler arasında gerçekleşen ilişki ve etkileşimlerin (Anderson, 2004), örgüt iklimi ve kültürünün (Hook, 2006) ve okul müdürünün öğretmen liderliğini algılayış biçiminin (Can, 2009b; Mangin, 2007) öğretmenlerin liderlik davranışları sergilemelerinde etkili olduğu görülmektedir. Bu bağlamda, öğretmenlerin okul içinde ve dışında liderlik davranışları sergilemelerinde farklı etmenlerin etkili olduğu ve bu etmenlerin öğretmenlerin liderlik rollerine ilişkin beklentilerini ve algılarını biçimlendirdiği söylenebilir.

Araştırmada elde edilen diğer bir bulgu, cinsiyet değişkenine göre öğretmenlerin liderlik rollerine ilişkin beklentilerinin kurumsal gelişme ve meslekî gelişim boyutlarında anlamlı bir biçimde farklılaştığı, algılarının ise öğretmen liderliğinin alt boyutlarında anlamlı bir biçimde farklılaşmadığı yönündedir. Bu bulgu ile Beycioğlu ve Aslan'ın (2012) araştırma bulguları örtüşmektedir. Araştırmadan elde edilen bulgular incelendiğinde, beklenti boyutunda anlamlı farklılıkların kadın öğretmenlerin lehine olduğu, alg1 boyutunda ise erkek ve kadın öğretmenler arasında anlamlı farklılıklar olmamasına rağmen kadınların öğretmen liderliğine ilişkin algılarının erkeklere göre daha yüksek olduğu görülmektedir. Bu bulgu kadın öğretmenlerin, öğretmen 
liderliğini daha fazla benimsedikleri ve liderlik rollerini daha fazla içselleştirdikleri biçiminde yorumlanabilir. Adams ve Hambright (2004) son yıllarda öğretmen lider yetiştirme programlarına kadın adayların ilgisinin arttığını ve kadınların liderlik rollerini daha fazla benimsediklerini belirtmektedir. Beycioğlu ve Aslan (2012) ise kadınların öğretmen liderliğine yönelik ilgilerinin yüksek olmasını, öğretmen liderliğinin daha demokratik, işbirlikçi ve etkileşim odaklı bir anlayışa sahip olması nedeniyle bir bakıma eril duruşla özdeşleşen geleneksel liderlik yaklaşımlarından farklılaşmasıyla ilişkilendirmektedir. Tyack (1974) geleneksel liderlik anlayışında kadınların liderlik rolleri üstlenmelerinin zorluğundan söz etmekte ve çoğu zaman kadın rollerinin izleyen olmakla sınırlı kaldığını ifade etmektedir (akt. Schoetzau, 1998). Ayrıca, Anderson (2004) kadın öğretmenlerin informel liderlik rollerinde daha başarılı ve etkili olabileceğini ileri sürmektedir. Bu bağlamda, öğretmen liderliğinin informel bir boyutu sahip olduğu da düşünüldüğünde, liderlik rolleri üstlenmek isteyen kadın öğretmenlerin öğretmen liderliğine yönelik beklenti ve algılarının yüksek olması doğal karşılanabilir.

Araştırmanın diğer bir bulgusu, yaş değişkenine göre ortaöğretim okulu öğretmenlerinin liderlik rollerine ilişkin beklentilerinin anlamlı bir farklılık göstermediği, algılarının ise yalnızca öğretmen liderliğinin kurumsal gelişme boyutunda anlamlı bir biçimde farklılaştığı yönündedir. Araştırmanın bu bulgusu, farklı yaş gruplarından öğretmenlerin liderlik rollerini üstlenme noktasında beklentilerinin benzeştiği biçiminde yorumlanabilir. Bununla birlikte, öğretmenlerin liderlik davra- 
nışlarını sergilemelerine ilişkin algılarında kurumsal gelişme boyutunda anlamlı farklılıkların oluştuğu görülmektedir. Araştırma sonuçları, 21-30 yaş ve 41 yaş ve üzerinde bulunan öğretmenlerin öğretmen liderliğini ilişkin algılarının 31-40 yaş arası öğretmenlerin algılarından anlamlı bir biçimde daha yüksek olduğunu göstermektedir. Başka bir ifadeyle, öğretmenlerin liderlik rollerine yönelik algılarında yaşlarıyla doğru orantılı bir artış gerçekleşmemektedir. Bu yönüyle mevcut bulgu, araştırmanın ilginç bulgularından biri olarak değerlendirilebilir. Öte yandan, 21-30 yaş arasındaki öğretmenlerin göreve yeni başlayan öğretmenler olduğu düşünüldüğünde, liderlik davranışlarını daha fazla sergileme ve okul gelişim sürecine daha fazla katkı sağlama noktasında daha istekli davranabilecekleri düşünülebilir. 41 yaş ve üzerinde bulunan öğretmenlerin de liderlik rollerine kendilerini daha fazla hazırladıkları ve bu süreçte informel liderlik davranışları sergilemeye daha fazla odaklandıkları söylenebilir. Bu noktada araştırma bulgularının tartışılmasında, gerek yurt içi gerekse yurt dışı eksenli alanyazında konuya ilişkin yapılan ampirik çalışmaların oldukça az olmasının önemli bir sınırlılık oluşturduğunu ifade etmek mümkündür.

Araştırmadan elde edilen bir diğer bulgu, ortaöğretim okulu öğretmenlerinin öğretmen liderliğine ilişkin beklentilerinin kıdem değişkenine göre öğretmen liderliğinin kurumsal gelişme, meslekî gelişim ve meslektaşlarla iş birliği boyutlarında anlamlı bir biçimde farklılaşmamış olmasıdır. Başka bir deyişle, farklı kıdem gruplarından öğretmenlerin liderlik rollerine ilişkin beklentileri benzerlik göstermektedir. Bu bulgu ile Beycioğlu ve Aslan'ın (2012) araştırma bulgu- 
ları paralellik göstermektedir. Bununla birlikte, öğretmen liderliğinin meslekî gelişim boyutunda öğretmenlerin kıdemleriyle birlikte beklentilerinin de arttığı görülmektedir. Bu bulgu, meslekte deneyim kazanan öğretmenlerin meslektaşlarına örnek olmak, onlardan yeni şeyler öğrenmek ve onların meslekî gelişimlerine yardımcı olmak için öğretmen liderliğinden daha fazla büyük bir beklenti içinde oldukları anlamına gelebilir. Öte yandan, öğretmenlerin liderlik rollerine yönelik algılarında kurumsal gelişme ve meslektaşlarla iş birliği boyutlarında anlamlı farklılıkların oluştuğu görülmektedir. Ayrıca, her iki boyutta da 1-5 y1l k1deme sahip göreli olarak daha az deneyimli öğretmenlerin algılarının daha yüksek olduğu görülmektedir. Bu bulgu, Beycioğlu ve Aslan (2012) tarafından yapılan ve kıdemi daha fazla olan öğretmenlerin öğretmen liderliğine ilişkin algılarının kıdemi daha az olan öğretmenlere göre daha yüksek olduğunu ortaya koyan araştırma sonuçlarıyla örtüşmemektedir. Mevcut çalışmada mesleğe yeni başlayan öğretmenlerin öğretmen liderliğine ilişkin algılarının daha yüksek olduğunun saptanması, bu öğretmenlerin öğretim rolleriyle birlikte liderlik rollerini üstlenme noktasında daha istekli oldukları biçiminde yorumlanabilir. Bununla birlikte, mesleğe yeni başlayan öğretmenler meslekte deneyim kazanmak ve gerçekleştirdikleri öğretimin kalitesini artırmak amacıyla diğer meslektaşlarıyla iş birliği içinde çalışmaya daha eğilimli olabilirler.

Araştırmada son olarak ortaöğretim okulu öğretmenlerinin öğretmen liderliğinin kurumsal gelişme, meslekî gelişim ve meslektaşlarla iş birliği boyutlarına ilişkin algı ve beklentileri arasındaki ilişkiler 
incelenmiştir. Araştırma sonuçları, öğretmenlerin liderlik rollerine ilişkin beklentileri ve algıları arasında pozitif yönde anlamlı ilişkilerin olduğunu göstermektedir. Beycioğlu ve Aslan'ın (2012) araştırma bulguları bu bulguyu destekler niteliktedir. Diğer bir ifadeyle, öğretmenlerin liderlik rollerine ilişkin beklentileri ve algıları aynı yönde hareket etmekte; beklenti arttıkça algı, algı arttıkça da beklenti düzeyi artmaktadır. Liderlik davranışları sergileyen öğretmenlerin, meslekî gelişimlerini sürdürmek, gerçekleştirdiği öğretimin kalitesini artırmak ve okul gelişim sürecine katkı sağlamak gibi farklı beklentileri olabilir. Can (2009a) öğretmen liderlerin sınıf için öğrencilere ve sınıf dışında diğer öğretmenlere liderlik edebildiklerini, diğer öğretmenlerin meslekî gelişimlerini sürdürmelerine yardımcı olduklarını ve öğrenci başarısının artırılması süreçlerini kolaylaştırdıklarını ileri sürmektedir. Bununla birlikte, Katzenmeyer ve Moller (2009) liderlik davranışları üstlenen öğretmenlerin kendi meslekî gelişimleri sürdürmeye de odaklanabildiklerini ileri sürmektedir. Bu noktada, liderlik davranışları sergileyen öğretmenlerin bu davranışlarını belli birtakım beklentilerin üzerine yapılandırdıkları düşünülebilir. Bu bağlamda, araştırmanın bu bulgusunun beklentilerle uyum içinde olduğunu söylemek mümkündür.

Araştırma sonuçları, katılımcıların öğretmen liderliğinden beklentilerinin yüksek olduğunu göstermektedir. Bu sonuç, katılımcıların öğretmen liderliğine ilişkin pozitif yönde bir tutum sergilediklerini göstermesi açısından önemli görülebilir. Ancak öğretmenlerin liderlik rollerini sergileme düzeyleri daha düşüktür. Araştırmada elde edilen bu sonuca dayalı olarak öğretmenlerin liderlik rollerini üstlenmeleri ko- 
laylaştıracak ve liderlik rollerine ilişkin beklentilerini gerçekleştirmelerine yardımcı olacak düzenlemelerin yapılması önerilebilir. Özellikle öğretmen liderliğinin yaygınlaşmasını sağlayacak okul tabanlı etkinlikler ve paylaşımlarla konuya ilişkin öğretmenlerin ve okul yöneticilerin farkındalığı artırılabilir ve bu şekilde öğretmenlerin liderlik potansiyellerinden okul gelişimi sürecinde daha fazla yararlanılabilir. Öğretmen liderliği daha demokratik, işbirlikçi ve katılımcı bir anlayış temeline oturması nedeniyle geleneksel müdür odaklı liderlik yaklaşımından farklılaşmaktadır. Bu bağlamda, okulda öğretmenlerin liderlik davranışlarının benimsendiği ve desteklendiği bir kültür oluşturma noktasında birtakım düzenlemeler yapılabilir. Ayrıca, okul yöneticilerine verilecek eğitimlerde öğretmen liderliğinin öğrenci öğrenmesinin artırılmasına yönelik potansiyel gücü vurgulanarak okul müdürlerine öğretmenlerin iş birliği yapabilecekleri, olumlu ve sağlıklı bir okul kültürünün oluşturulması noktasında destek sağlanabilir.

Araştırma sonuçları kadın öğretmenlerin, öğretmen liderliğini daha fazla benimsedikleri ve liderlik rollerini daha fazla içselleştirdiklerini göstermektedir. Bu bağlamda, kadın öğretmenlerin liderlik rollerini ön plâna çıkarmaları önemsenmeli ve bu yönde gelişen davranışları teşvik edilmelidir. Ayrıca araştırma sonuçlarına göre, öğretmen liderliğinin kurumsal gelişme ve meslektaşlarla iş birliği boyutlarında mesleğe yeni başlayan öğretmenlerin algılarının daha yüksek olduğu anlaşılmaktadır. $\mathrm{Bu}$ bağlamda velilerin okul süreçlerine daha fazla katılımlarının sağlanması, okula kaynak tahsis edilmesi ve okula ilişkin bilgi ve raporların hazırlanması süreçlerinde göreve yeni başlayan 
öğretmenlerin enerji ve potansiyellerinden yararlanmak, yerinde bir yaklaşım olabilir.

Mevcut araştırmada, ortaöğretim düzeyindeki okullarda görev yapan öğretmenlerin öğretmen liderliğine ilişkin beklenti ve algıları farklı değişkenlere göre irdelenmiştir. Bununla birlikte, öğretmenlerin liderlik davranışlarına ilişkin yapılan ampirik çalışmaların oldukça sınırlı olması bu araştırmadan elde edilen bulguların tartışılmasında oldukça önemli bir sınırlılık oluşturmuşstur. Bu bağlamda, öğretmenlerin liderlik davranışlarına ilişkin farklı eğitim kademlerinde, farklı araştırma yöntemleriyle ve farklı değişkenler kullanılarak yapılacak çalışmaların alana önemli katkı sağlayacağı düşünülmektedir. Özellikle öğretmenlerin liderlik davranışları sergilemelerini etkileyen örgütsel ve kişisel etmenlerin derinlemesine inceleneceği araştırmalara ihtiyaç duyulduğu söylenebilir.

\section{Kaynakça}

Adams, K. L. ve Hambright, W. G. (2004). Encouraged or discouraged? Women teacher leaders becoming principals, the clearing house. A Journal of Educational Strategies, Issues and Ideas, 77(5), 209-212.

Anderson, K. D. (2004). The nature of teacher leadership in schools as reciprocal influences between teacher leaders and principals. School Effectiveness and School Improvement, 15(1), 97-113.

Barth, R. S. (1990). Improving schools from within. Teachers, parents, and principals can make the difference. San Francisco, CA: Jossey-Bass. 
Beachum, F. ve Dentith, A. M. (2004). Teacher leaders creating cultures of school renewal and transformation. The Educational Forum, 68(3), 276-286.

Beycioğlu, K. ve Aslan, B. (2010). Öğretmen liderliği ölçeği: Geçerlik ve güvenirlik çalışması. Ilkoğretim Online, 9(2), 764-775.

Beycioğlu, K. ve Aslan, B. (2012). Öğretmen ve yöneticilerin öğretmen liderliğine ilişkin görüşleri: Bir karma yöntem çalışması. Kuram ve Uygulamada Ĕgitim Yönetimi [Educational Administration: Theory and Practice ], 18(2), 191-223.

Buckner, K. G. ve McDowelle, J. O. (2000). Developing Teacher Leaders: Providing Encouragement, Opportunities, and Support. NASSP Bulletin, 84, 35-41.

Busher, H. ve Harris, A. (1999). Leadership of school subject arenas: Tensions and dimensions of managing in the middle. School Leadership and Management, 19(3), 305-317.

Camburn, E., Rowan, B. ve Taylor, J. E. (2003). Distributed leadership in schools: The case of elementary schools adopting comprehensive school reform models. Educational Evaluation and Policy Analysis, 25, 347-373.

Can, N. (2009a). Öğretmen liderliği. Ankara: Pegem Akademi.

Can, N. (2009b). Öğretmenlerin sınıfta ve okulda liderlik davranışları. Gaziantep Üniversitesi Sosyal Bilimler Dergisi, 2, 385-399.

Coleman, A. (2006). Collaborative leadership in extended schools leading in a multi-agency environment. National College for School Leadership (NCSL). 18.03.2013, http://dera.ioe.ac.uk/7196/1/extended-schools.pdf.

Conzemius, A. ve O'Neill, J. (2001). Building shared responsibility for 
student learning. Alexandria, Virginia, USA: Association for Supervision and Curriculum Development.

Crowther, F. ve Olsen, P. (1997). Teachers as leaders - an exploratory framework. International Journal of Educational Management, 11(1), 6-13.

DuFour, R., Eaker, R. ve DuFour, R. (2005). Recurring themes of professional learning communities and the assumptions they challenge. R. DuFour, R. Eaker ve R. DuFour (Ed.), On common ground: The power of professional learning communities içinde (1-6). Bloomington, IN: Solution Tree.

Frost, D. (2008). 'Teacher leadership': Values and voice. School Leadership and Management, 28(4), 337-352.

Frost, D. ve Harris, A. (2003). Teacher leadership: Towards a research agenda. Cambridge Journal of Education, 33(3), 479-498.

Fullan, M. G. (1994). Teacher leadership: A failure to conceptualize. D. R. Walling (Ed.), Teachers as leaders içinde (241-253). Bloomington, IN: Phi Delta Kappa Educational Foundation.

Fullan, M. (2008). What is worth fighting for in the principalship? (2. bask1). New York: Teachers College.

Gehrke, N. (1991) Developing teachers' leadership skills. ERIC Digest ED330691.

Grant, C. (2006). Emerging voices on teacher leadership: Some South African view. Educational Management Administration \& Leadership, 34(4), 511-532.

Gronn, P. (2009). From distributed to hybrid leadership practice. A. Harris (Ed.), Distributed school leadership: Different perspectives içinde (197-217). Dordrecht: Kluwer. 
Grubb, W. N. ve Flessa, J. J. (2006). “A job too big for one”: Multiple principals and other nontraditional approaches to school leadership. Educational Administration Quarterly, 42(4), 518-550.

Hallinger, P. (2005). Instructional leadership and the school principal: A passing fancy that refuses to fade away. Leadership and Policy in Schools, 4(3), 221-239.

Harris, A. (2002). School improvement: What's in it for schools? London: RoutledgeFalmer.

Harris, A. (2003). Teacher leadership as distributed leadership: heresy, fantasy or possibility? School Leadership \& Management, 23(3), 313-324.

Harris, A. (2011). System improvement through collective capacity building. Journal of Educational Administration, 49(6), 624-636.

Harris, A., Brown, D. ve Abbott, I. (2006). Executive leadership: Another lever in the system? School Leadership and Management, 26(4), 397-409.

Harris, A. ve Lambert, L. (2003). Building leadership capacity for school improvement. Maidenhead, Philadelphia: Open University.

Harris, A. ve Muijs, D. (2003). Teacher leadership: Principles and practice. London: National College for School Leadership. 11.01.2012,

http://www.nationalcollege.org.uk/index/docinfo.htm?id=17417.

Harris, A. ve Muijs, D. (2005). Improving schools through teacher leadership. Maidenhead, Philadelphia: Open University.

Helterbran, V. R. (2010). Teacher leadership. Overcoming "I'm just a teacher" syndrome. Education, 131(2), 363-371. 
Hook, D. P. (2006). The impact of teacher leadership on school effectiveness in selected exemplary secondary schools. Doktora tezi, Texas A\&M University. ProQuest Dissertations and Thesis database. (UMI No. 3219160).

Karasar, N. (2009). Bilimsel araştırma yöntemi (19. baskı). Ankara: Nobel.

Katzenmeyer. M. ve Moller, G. (2009). Awakening the sleeping giant. Helping teachers develop as leaders (3. bask1). Thousand Oaks, California: Corwin.

Lambert, L. (1998). Building leadership capacity in schools. Alexandria, Virginia: Association for Supervision and Curriculum Development.

Lambert, L. (2003). Leadership capacity for lasting school improvement. Alexandria, Virginia: Association for Supervision and Curriculum Development.

Lambert, L. (2005). What does leadership capacity really mean? Journal of Staff Development, 26(2), 38-40.

Leithwood, K. (2003). Teacher leadership: Its nature, development, and impact on schools and students. M. Brundrett, N. Burton, R. Smith (Ed.), Leadership in education içinde (103-117). Thousand Oaks, CA: Sage.

Leithwood, K. ve Jantzi, D. (2000). Principal and teacher leadership effects: A replication. School Leadership \& Management: Formerly School Organisation, 20(4), 415-434.

Lieberman, A. ve Miller, L. (2005). Teachers as leaders. The Educational Forum, 69(2), 151-162.

Lieberman, A., Saxl, E. R. ve Miles, M. B. (2000) Teacher leadership: 
Ideology and practice. The Jossey-Bass Reader on Educational Leadership içinde (339-345). San Francisco, CA: Jossey-Bass.

Mangin, M. M. (2007). Facilitating elementary principals' support for instructional teacher leadership. Educational Administration Quarterly, 43(3), 319-357.

Muijs, D. ve Harris, A. (2003). Teacher leadership - improvement through empowerment? An overview of the literature. Educational Management and Administration, 31(4), 437-448.

Muijs, D. ve Harris, A. (2007). Teacher leadership in (in)action. Three case studies of contrasting schools. Educational Management Administration \& Leadership, 35(1), 111-134.

Murphy, J. (2005). Connecting teacher leadership and school improvement. Thousand Oaks, California: Corwin.

Newmann, F. M. ve Wehlage, G. G. (1995). Successful school restructuring. A report to the public and educators (Report No: R117Q00005-95). 12.04.2012, http://llanes.auburnedu/cimjournal/ Vol1/No1/success.pdf.

Schoetzau, E. S. (1998). Principals' support for teacher leaders at elementary schools in a large suburban school district in Virginia. 11.006.13,

http://scholar.lib.vt.edu/theses/public/etd-22298-16523/materials /drellen.pdf.

Sergiovanni, T. J. (2001). Leadership: What is in it for schools? New York: RoutledgeFalmer.

Sergiovanni, T. J. (2007). Rethinking leadership. A collection of articles (2. bask1). Thousand Oaks, California: Corwin.

Spillane, J. P. ve Healey, K. (2010). Conceptualizing school leadership 
and management from a distributed perspective. An exploration of some study operations and measures. The Elementary School Journal, 111(2), 253-281.

Walker, D. (2002). Constructivist leadership: Standards, equity, and learning-weaving whole cloth from multiple strands. L. Lambert, D. Walker, D. Zimmerman, J. Cooper, M. Lambert, M. Gardner and P. Slack (Ed.), The constructivist leader içinde (1-33). New York: Teachers College.

York-Barr, J. ve Duke, K. (2004). What do we know about teacher leadership? Findings from two decades of scholarship. Review of Educational Research, 74(3), 255-316.

Zinn, L. F. (1997). Supports and barriers to teacher leadership. Reports of teacher leaders. Paper presented in the Annual Meeting of American Educational Research Association. Chicago, IL, (24-28 Mart, 1997). 